\title{
GENERAL PROBLEMS
}

\section{OF THE MODERN RESEARCH ANID INNOVATION POLICY}

https://doi.org/10.15407/scine17.05.003

KOTLYAREVSKYY, Ya. V.' (https://orcid.org/0000-0003-3542-6952), and SOKOLOVSKA, A. M. ${ }^{2}$ (https://orcid.org/0000-0002-1022-8215)

'Ministry of Finance of Ukraine,

12/2, Mykhailo Hrushevskyi St., Kyiv, 02000, Ukraine,

+380 442015630 , infomf@minfin.gov.ua

${ }^{2}$ Academy of Financial Management, 38, Druzhby Narodiv Blvd, Kyiv, 01103, Ukraine,

+380 44277 5115, afu@afu.kiev.ua

\section{THEORETICAL AND APPLIED \\ ASPECTS OF THE DEVELOPMENT OF REFORM INSTITUTIONS IN GLOBAL AND NATIONAL CONTEXT}

Introduction. Uncertainty in assessing the results of public policy reforms and lack of methodological consensus on the most appropriate approaches to the design and implementation of economic reforms and further complication of institutional conditions in the global and national terms require more thorough consideration of concepts related to knowledge and systematization of the content, structure, technology of implementation and evaluation of reforms and their outcomes.

Problem Statement. Exacerbating contradictions and accumulating crises in the world economy, the need for fiscal consolidation and simultaneous stimulation of economic growth of national economies in the medium term require the refinement of scientific approaches and the development of relevant aspects of the most transparent, accountable, and rational design of national reform institutions.

Purpose. The purpose of this research is to generalize, to structure, and to systematize the information on theoretical and applied foundations of public policy reforms implementation in the context of developing approaches to design and evaluation of their outcomes and to determine the pathway towards ensuring efficiency of economic reforms in Ukraine.

Materials and Methods. Methods of retrospective and comparative analysis have been used to identify the evolution of categorical-conceptual and methodological toolkit of the reform theory; factual analysis has been used to substantiate the pluralism of approaches of scientific schools and international organizations to the determination of reforms, their content, and outcomes.

Results. The approaches used by researchers for the analysis of reforms have been systematized with focus on the importance of understanding the challenges related to the social and redistributive effects of reforms; the approaches to the structuring the strategic and tactical aspects of reform on the basis of identification of the national institutions of reforms have been described.

Conclusions. The theoretical and applied aspects of research and regulation of public policy reform processes in global and national contexts have been generalized, approaches to the development of national reform institutions have been proposed.

Keywords: reforms, theory of reforms, economy, institutions, inclusion, and public policy.

Citation: Kotlyarevskyy, Ya. V., and Sokolovska, A. M. Theoretical and Applied Aspects of the Development of Reform Institutions in Global and National Context. Sci. innov. 2021. V. 17, no. 5. P. 3-19. https://doi.org/ $10.15407 /$ scine17.05.003 
Introduction. Reforms in Ukraine and other countries in a state of transformation, both initiated by the national governments and those implemented upon recommendations (insistence) of international financial organizations, as a condition for financial assistance, have raised several questions, the answers to which are important both for the development of science and for the improvement of reform processes effectiveness. Why are some reforms successful while others fail? Why do the same reforms lead to different results in different countries? Are there the general rules for managing the reform processes? Why does assistance in implementing reforms provided by the international organizations as donors and stakeholders of transformations of national institutions is not always effective?

The generalization of answers to these questions provided by leading researchers and practitioners from around the world, and the identification of ways to improve the effectiveness of economic reforms in Ukraine on this basis is the purpose of this research.

The analysis focuses on the two areas of economic reforms research:

- determining the list of necessary reforms and general approaches to organization of their implementation, compliance with which is a prerequisite for successful transformation (this direction is developed within the general theory of reforms) and analyzing the consequences of the reforms in individual countries or groups of countries in terms of evaluating their effectiveness.

Ensuring the effectiveness and tangible socioeconomic results of external financial assistance from international organizations and/or evaluation of its results is a controversial issue for many researchers. There is no consensus among the experts concerning which reform programs should be considered successful, since the international economic statistics and data on the existing disparities of economic development, have indicated a restrained positive economic effect from externally supported programs of economic reforms and structural transformations [1,2]. Even in the region of Africa, where there is a significant economic boom against the background of strategic investors competition (USA, EU, and China), the experts have noted that in general, the level of transformations for the better is insufficient in terms of economic growth. More noticeable is the progress in the economies that have outpaced growth as a result of extensive and unpredictable factors (such as exploration and the start of industrial use of hydrocarbon deposits), while the countries with more thorough and planned structural transformations of institutions on the basis of in-depth cooperation with international organizations and ambitious reform programs have shown, at best, a rate comparable to that of the world economic growth. Moreover, lately, the expert community more and more frequent comes to conclusion that there is a correlation between the amount and effectiveness of international assistance programs in accordance with the geopolitical configurations, which can be traced in functioning of relevant international platforms and organizations [3, 4].

Presentation of the material. The study of the methodological basis for the content and essence of reforms naturally begins with research by V. Polterovich who defines the reform as a transformation of economic institutions, as a result of purposeful measures of various scales, which are implemented according to a certain plan. He considers "a stream of institutional innovations" triggered by these measures to be a sign of reforms. In his opinion, unforeseen outcomes of macroeconomic management in the reform process and the main risk for reform implementation are institutional traps that should be avoided through predicting them at the preparatory stage.

V. Polterovich defines "reform" based on its content and the nature of transformations that accompany it, whereas H. Hill takes into consideration its orientation (ultimate result), emphasizing the limitations of its (orientation) narrow interpretation as increasing productivity and growth rate, which is typical for definitions as formulated by many economists. In his view, "reform" is a longterm and significant policy transformation that 
improves overall socio-economic well-being in accordance with its objective function that takes into account the redistributive and the environmental aspects. It is the provision of general welfare, the achievement of public rather than personal interests (the interests of individual ruling circles, big business, etc.) that is the main rationale for reform [6].

Economic reforms are the subject of both theoretical and empirical research in terms of their various aspects. According to V. Polterovich, the applied aspect of these studies may be defined as the creation of a kind of "guide for reformers." A way to solve this problem is to try to offer reformers in Latin America, and later in Eastern Europe, a "desirable package of economic policy reforms," called the Washington Consensus. Another way is to identify common approaches to economic reforms (rules for their implementation), the application of which may give reformers a chance to succeed.

The package of reforms that are necessary at the first stage of transformations in developing countries and agreed between economic officials of the United States, the IMF, and the World Bank, includes 10 measures. Among them, there are restoring the fiscal discipline; curbing inflation; changing priorities in spending budget funds by directing them to health care, education, and investment in public infrastructure; tax reform aiming at expanding the tax base and setting moderate marginal tax rates; liberalizing foreign trade; privatization; deregulation, etc. The implementation of these measures should have created the necessary prerequisites for the effective functioning of a market economy and economic growth [7].

The lack of economic growth as a consequence of reforms based on the Washington Consensus in the 1980s and 1990s raised doubts about the expediency of absolutizing their significance and the need to implement the entire list of measures systematized by D. Williamson. In particular, D. Rodrick states that South Korea that is one of the most successful countries, has implemented only five of the ten recommendations [8]. Other authors ha- ve acknowledged the weakness of the Washington and even Post-Washington consensus because of the lack of an attempt to define the sequence of transformations or to link their nature to existing institutions [5]. Having analyzed the whole toolkit proposed by the Washington Consensus for economic growth, J. Stiglitz comes to the conclusion that this toolkit is not suitable for all countries. In particular, the focus on inflation, a major macroeconomic disease in Latin America that gave rise to the Washington Consensus, has led to macroeconomic policies that are not conducive to long-term economic growth and distracts from other major sources of macroeconomic instability, namely, weak financial sectors. Such a policy instrument as budget deficit also should not be absolutized, because, according to J. Stiglitz, there is no unambiguous optimal level of budget deficit. The optimal deficit depends on circumstances, including the cyclical state of economy, the future growth prospects, the public spending, the depth of financial markets, as well as on the national savings and national investment [9]. Critical remarks have been also made about other economic instruments of the Washington Consensus: rapid privatization without necessary institutional infrastructure, including competitive markets and regulators; trade liberalization that is neither necessary nor sufficient to create a competitive and innovative economy; underestimation of good governance as a vital institution for development. Based on the results of their analysis, J. Stiglitz has noted the need to expand not only the set of measures, but also the goals of economic transformations. According to him, the goal of the policy should be not only to increase GDP, but also to raise living standards, including improving healthcare and education. "We seek sustainable development, which includes preserving our natural resources and maintaining a healthy environment. We seek equitable development, which ensures that all groups in society enjoy the fruits of development, not just the few at the top. And, we seek democratic development, in which citizens participate in a variety of ways in making the deci- 
sions which affect their lives." Considering these ideas to be the basis of emerging post-Washington consensus, J. Stiglitz has made another important conclusion, "whatever the new consensus is, it cannot be based on Washington." In order for policies to be sustainable, they must receive ownership by developing countries, become a sort of conscious necessity. "The second principle of the emerging consensus is a greater degree of humility, the frank acknowledgment that we do not have all of the answers. Continued research and discussion not just between the World Bank and the International Monetary Fund, but throughout the world is essential if we are to better understand how to achieve our many goals" [9].

Subsequently, D. Williamson, the Consensus founder, acknowledged that in fact the Washington Consensus had ceased to exist, at least, there was no agreement on the main provisions of the economic reform agenda between the US administration and international financial institutions [10].

Thus, in the early 2000s, the category of "postWashington Consensus" (or the Barcelona Development Agenda) came into circulation. It is named after the venue of the conference in September 2004, the final statement of which was signed by several leaders of economic thought). In contrast to the previous concept, it is based on the recognition of the need to differentiate institutional approaches to reform in different countries, as well as of the importance of effective government intervention in a market economy. Within this approach, the issues of poverty reduction and provision of social services to all segments of the population have been given more importance [11].

The criticism of the Washington Consensus and the recognition of its limitations have intensified developing other approaches to supporting reforms in transition and developing economies, namely the identification of general rules of implementation, which are based on the generalized experience of economic reforms in different countries and could guarantee successful reforms in other countries. However, agreeing on some app- roaches, the researchers and experts express opposing views on the other ones. This reflects the fact that, on the one hand, each reform is often implemented in unique place and time, and therefore each country and each reform shall go its own special way [12]. However, on the other hand, the problems to be solved in the process of reforms in different countries are often quite similar, which makes it possible to apply such approaches to their solution. Of course, as R. Bird points out, a comparative approach cannot offer clear prescriptions as to what should be done at any given time in a given country. However, it can be very useful to study how different countries solve such problems and try to reveal the main factors that determine how successfully they have been solved [12].

According to V. Polterovich, the success of reforms depends on preparedness, sequence, and pace [5]. In this context, it is interesting to analyze the results of comparing the shock and the gradual approaches to choosing appropriate sequence and pace of reforms $[13,14]$.

$H$. Hill notes that effective reform requires a coherent intellectual agenda, analysis of what, how, and in what sequence needs to be done [6]. Other researchers have emphasized the fundamental role of policy cycles in shaping the institutional framework for reform [15].

J. Williamson in his research The Political Economy of Policy Reform (1994) has formulated 16 hypotheses about what makes reform practicable and successful. Among them there are the following hypotheses: crises as a driver of reform; strong external support (assistance) as an important condition for successful reform; success (advantages) of authoritarian regimes in implementation of reforms; the need for government support of legislative reform; social consensus as a powerful factor in facilitating reforms; the importance of a comprehensive program that can be rapidly implemented as a condition for successful reform; the expediency of masking the intentions of the reformers in front of the general public and the effective use of the media, etc. 
However, as D. Rodrick comments on these hypotheses, eventually, J. Williamson himself has admitted the lack of completely reliable empirical generalizations, and any of these hypotheses is neither necessary nor sufficient for successful reform [8].

The critical analysis of these hypotheses, including the hypothesis of crisis as a driver of reform, has been presented in The Political Economy of Policy Reform: Insights from Southeast Asia, where the author notes that, on the one hand, a crisis may be helpful in persuading the community that the current order is unacceptable and requires change. Political leadership may be emboldened and willing to tackle difficult issues. However, on the other hand, not all crises trigger major reforms. Instead they may result in failed states or at least an inability to seize the opportunity to reform. That is, the hypothesis only works in certain circumstances [6].

The author's remarks on the hypothesis of external support (assistance) as an important condition for successful reform are also interesting. Referring to E. Krueger and S. Rajapatirana [16], according to whom international agencies can play an effective role if there is a domestic interest in and will for reform, $H$. Hill notes that in the absence of these factors, foreign aid encourages the recipient countries to postpone difficult policy reforms, so the implementation is likely to be spasmodic, and the reforms will therefore generally not be durable. The author's team led by S. Haggard has drawn consonant conclusions, noting that it makes no sense to lend to a government that lacks political interest or the ability to carry out a reform program. There is no sense lending to a government that lacks the political interest or capacity to pursue a program to its conclusion. Lending in such circumstances may even establish perverse incentives, allowing governments to postpone reform and continue with misguided policies [17]. These arguments are also consistent with the results of econometric studies, according to which foreign aid promotes growth only when there has been a "good policy" in place [6].
The hypothesis of the success of authoritarian regimes in implementing reforms has been discussed. In particular, according to $\mathrm{H}$. Hill, it might be argued that while reform is slower under a democratic regime, it is likely to be more durable since the reform process will be consensus-driven, with greater attention paid to potential losers. However, a high pace of reform does not guarantee its success. Therefore, other authors suggest that at the initial stage of reform, the independence or autonomy of the executive power is necessary, while support and consensus play important role at the later stages. Having analyzed the reforms in different countries, they conclude that the history of the 1970s and 1980s shows that authoritarian rule does not necessarily yield positive results, and that governments cannot indefinitely suppress or marginalize the interests of major groups. In any case, establishing the credibility of reform and institutionalizing its gains under democratic rule ultimately require building support for the program through the party system and with the electorate at large [17].

Contrary to D. Williamson's hypothesis about the expediency of masking the intentions of the reformers in front of the general public, A. Olofsgard states that the political support of a "real" reformist government, which depends on its ability to reliably signal its intentions is important for continuing the reform process.

R. Bird has made important generalizations about how a successful reform should be implemented, by the example of the tax reform in Indonesia in the early 1980s:

- In the first place, and importantly, the tax reform was clearly "owned" by the Indonesians. Although considerable use was made of foreign expertise (hired by the government itself), the reform was initiated and shaped by a strong Minister of Finance in close collaboration with the planning ministry.

- Secondly, ample time (about two years) was devoted to preparing and evaluating policy options - which were, in condensed form, often presented to and debated before, the Minister 
himself - and then, importantly, to drafting the necessary legislation to implement the options selected.

- Thirdly, most revenue sources (except tariffs) were included in the reform, and attention was paid not only to tax structure issues but also to tax administration and compliance issues. The reform was intended to be, and largely was, unusually comprehensive.

Finally, significant funds were invested both in training tax officials to manage the new system and in modernizing the information component of the tax administration.

At the same time, Indonesia's experience refutes the hypothesis of a link between reforms and crises. According to R. Bird, unlike most tax reforms in developing countries, it was not done in response to an immediate and urgent revenue crisis but rather in anticipation of a likely future revenue need arising from diminishing petroleum revenues [6].

In addition, R. Bird makes some other important generalizations about the implementation of successful tax reforms, which can be extended to reforms in general:

- The reform shall take into account the initial conditions of the country;

- In order for the reform to be successful, there shall be internal ownership of the initiatives;

- Successful reform requires policy makers and experts who have detailed knowledge and involvement in the existing system and who take responsibility for the reform [6].

In our opinion, an intermediate conclusion on more emphasized economic nature of the essence of modern reforms, the universality of economic criteria for their initiation, implementation, and evaluation of effectiveness may be considered important for further scientific discourse on the essence of modern reforms and for highlighting applied aspects of research on this issue. In this context, we propose a definition of reform as a set of purposeful structural and institutional transformations in a particular area of public policy, which that significantly change the rules and regula- tions of public interest and distribution of public goods in the process of inclusive socio-economic development.

The conclusions of the Organization for Economic Cooperation and Development (OECD), as prepared within the framework of the Make Reform Happen project (lessons from OECD countries) that in the conditions of post-global financial crisis focuses on summarizing the experience of reforms in several countries, emphasize the feasibility of preferring a consensus policy of multilateral agreement rather than achieving stakeholder flexibility, which should be based on strong communication and in-depth research. Among other important components of favorable development of the reform agenda the researchers mention strong leadership and institutions, proper sequence and time of reforms, as well as an effective strategy of interaction with opponents of the reform process. At the same time, along with the emphasis on the predominantly institutional nature of these reform drivers (the text of the report repeatedly points out the convergence of policies and institutions and the path dependence), special focus is placed on the rehabilitation of public finance and the harmonization and combination of fiscal policy instruments with structural reforms aiming at economic growth. In the final conclusion, the authors have stated that the combination, adaptation, and combination of these factors in the form of a hybrid policy can guarantee the effectiveness of reforms [19]. It should be noted that the Ukrainian researchers have been considering the combination of research in the field of coordination of the institutional nature of structural transformations that usually form the basis of reform processes with sustainable public finance, which allows a deeper understanding of the theoretical and methodological framework.

As part of the ongoing discourse on finding the best principles for reform and development, the World Bank experts in the final report on the reforms of the 1990s have noted that some countries managed to sustain rapid growth through relatively modest reforms, while others failed to grow 
even after implementation of a wide range of reforms [21]. At the same time, summarizing the experience of reforms in the areas of agricultural sector liberalization and public-private partnership in water supply based on the analysis of its WB portfolio of projects, the experts stressed the following three key messages for effective engagement by development agencies in processes of sector level policy reform and operations:

In summary, the study points to:

1. The importance of good political economy analysis, applied early in the process, to effective donor engagement in sector policy reforms and operations.

2. The significance of a sustainable process of building coalitions for change that involves dialogue with a broad range of stakeholders, including client governments, donors, other development partners, and the public.

3 . The importance of promoting transformative processes of institutional change, including empowering forms of bottom-up accountability [22].

With the transition from the Washington to the Post-Washington Consensus, the expansion of the list of economic reform goals, in particular, including not only economic growth but also poverty reduction and other social goals, has created the preconditions for the World Bank to develop the Poverty and Social Impact Analysis (PSIA) tool. The main objective of this approach is to assist governments and donors in assessing expectations and preparing for the possible consequences of the proposed reforms, with a special focus on poverty and vulnerable populations, given the country's desire to develop its policymaking capacity. According to this methodology, the central place in the analytical calculations belongs to the social and economic aspects of the distributive effect of reforms, with focus on their sustainability and the risks associated with the social consequences of policy transformations. Within the methodology, there is a formalized analysis in the three areas: the possible consequences of reforms, based on probable factors (the ex-ante analysis); the analysis during the process of imp- lementing reforms; and the analysis of the actual results of the implemented reforms (the ex-post analysis). In 2002-2007, the World Bank system produced 156 analytical developments with the use of at least one of the elements of the PSIA methodology. These developments covered 14 sectors in 75 countries. Regarding the effectiveness of this approach, in the generalized materials of the World Bank it was noted that the results of quality control, monitoring, and evaluation within the PSIA approach were weak, in particular, not least because of internal problems of the Bank [23]. Despite these findings, in 2010, the PSIA Multi-Donor Trust Fund of USD 21.5 million was established. In 2010-2016, 237 projects for analyzing reforms in 83 countries, mostly developing economies, were financed from this fund. The results of this institution, as summarized in the final evaluation report on its activities, despite a high estimate of such components as the creation of knowledge, the promotion of recipients' awareness, and the dissemination in the World Bank system, are not unambiguous, especially in terms of assessing sustainable impact on the recipient countries. In particular, low capacity of national governments to use this methodology in assessing the redistributive effects of reforms has been identified as a particular challenge. It is also noted that the focus of reform research solely on the implications for poverty reduction and the social context limits the overall potential of the methodology. In addition to individual sectoral reforms in several countries, among the PSIA's greatest achievements, there are a well-established methodology, a knowledge base, and an extensive network of experts; some components continue to be used in World Bank procedures and policies (in particular, Development Policy Financing, Systematic Country Diagnostics, Environmental and Social Framework) [24]; and the Internet representation of the expert community is supported [25].

Along with the lack of significant results that would clearly indicate the existence of a successful and repetitive framework for reforms in international financial organizations and the shift in 
the focus towards the knowledge, operational, and technocratic aspects of reforms, there have been numerous discussions on the reform agenda in the scientific discourse. In particular, the authoritative researcher W. Easterly, who is known for his skeptical assessments of the consequences of reforms [26] has changed its opinion, as in his recent work he has reinterpreted the statistical data, highlighting the three new stylized facts: (1) policy outcomes worldwide have improved a lot since the 1990s, (2) improvements in policy outcomes and improvements in growth across countries are correlated with each other (3) growth has been good after reform in Africa and Latin America, in contrast to the "lost decades" of the 80 s and $90 \mathrm{~s}$. It should be noted that the author has concluded on the positive trends based on the achieved economic growth of the two regions (the average growth rates: $0.1 \%$ of GDP for Africa in 1980-98, 1.7\% of GDP for Africa in 1999-2015, $0.4 \%$ of GDP for Latin America in 1980-98, 2.1\% of GDP for Latin America in 1999-2015) [27].

On the basis of a deeper retrospective that covers these periods of time, one of the most authoritative representatives of the Harvard school M. Andrews has made somewhat opposite considerations. In his works, he states that the developing countries (these countries are usually the most active apologists for reforms) did not show a higher growth rate in 1900-2016 as compared with other divisions. In 2018, this statement allowed the author to draw an intermediate conclusion about no significant impact of reforms in most countries. However, the researcher associated some successes with "luck in development", i.e. the right choice of national economy sectors to focus efforts and to qualitatively improve the position of the relevant sector in global competition, the appropriate level of readiness of these economies to unforeseen opportunities in external environment, etc. [28]. Later, M. Andrews has come to a polemical conclusion about the developing countries: they have become overly dependent on aid as the key to their development, and the advice of aid organizations as the basis of their development strategies.
He compares the amount of the aid and the world GDP, "Aid, in 2015, from OECD member states, was USD 135 billion... a record. In current prices, world GDP in 2015 was USD 74,311.46 trillion" and concludes, "Do developing countries really think that they will actually become competitive on the basis of funding crumbs - and advice from the crumby funders? The funding agencies represent competitors who do compete, and it seems like they are not providing either the money or advice to make developing countries real competitors in their global growth competition" [29].

This, again, makes us think about the criteria for effectiveness and successfulness or imperfection of reforms, because, first, to consider the economic growth rates that are lower than the world average and thereby preserve inequality and imbalances to be effective and successful reforms is misleading in terms of the development of economic theory and public administration practice and, second, such a long period of observation and diversified approaches of outstanding researchers on the basis of the same statistical data make important the problem of spontaneous-to-purposeful transformations ratio under different institutional conditions.

Another annual report by OECD researchers in 2016, which focuses on a comparative analysis of structural reforms and economic development among member states, emphasizes the objective trends of slowing down reforms since 2013-2014. Mentioning the irregular pattern of reform implementation and the pinpoint nature of individual initiatives, the experts have concluded that reforms have a very limited, insignificant impact on the ability to find a balance for countries with the largest budget deficits [30]. Since 2017, the OECD has consciously focused its annual publications not only on comparative analysis of reforms, but also on evaluation of their priorities according to its own model, based on combination of quantitative analysis and institutional characteristics of countries. The first component is anchored in a decomposition of GDP growth into labor productivity and labor utilization (employ- 
ment). The second component is assessment of impact on inclusiveness and environmental sustainability. According to the procedure of the formal model, in the first step, indicators of economic outcomes are linked in pairs to relevant policies addressing them based on empirical evidence. Then, an outcome-policy pair is compared to the OECD average to identify performance on both policies and outcomes, given into account other socio-economic indicators [31].

The discussions on the content, institutional and politico-economic contexts for further implementation of reforms have been certainly not completed. This has been evidenced, in particular, by the exchange of expert opinions initiative under the auspices of the IMF. The study published in October 2019 is formatted as an internal discussion paper on the need for structural reforms in response to the continuing trend of weak economic growth in the medium term and limited fiscal space for the vast majority of advanced and developing economies. The authors have noted that the existing consensus on the need for economic reforms is accompanied by a lack of unified approaches to their political and economic content. In a general sense, they have defined this process as getting the balance between the expectations of a long-term positive effect of reforms and the political accountability for short-term negative consequences (primarily related to redistributive effects). Accordingly, the document deals with the issue of the political costs of reforms and the possibility of forming such a strategy and reform process, which would prevent negative political consequences.

One of the most important intermediate conclusions as formulated by the authors on the basis of empirical data is the statement that there are no statistically significant negative political consequences of reforms if they are implemented under relevant government program with the IMF [32]. Sometimes, it seems that, in government policy, this aspect of diversifying political risks by shifting some of the political responsibility onto international financial institutions outweighs the need to design a reform that would be more effective under a national consensus.

To summarize, the Western scholars have formulated the following main conditions for successful reforms: well-prepared national reform strategy that takes into account both international experience and the features and needs of national development; comprehensiveness of the proposed transformations; well-chosen priorities, sequence, and time for implementation of this or that reform, avoidance of reforms in the conditions of unfavorable national social and economic dynamics; political will to implement transformations; support to the government that implements reform from legislative bodies; consensus policy of multilateral agreement, which should be based on strong communications; monitoring, evaluation of effectiveness, and public reporting on reform progress.

Given this, as well as the lack of global consensus on universal recipes for reform and, at the same time, the need for many transformations in our country, the development of institutional aspects of reform, which have been understudied so far, but are important for the consensus agenda is an urgent research and practical task.

In Ukraine, after the radical economic (market) reforms of 1994-2004, which were accompanied by deepening contradictions, decline in production, the financial crisis of 1998-1999 and, finally, economic growth (in 2000-2003, it exceeded $7 \%$ on a year-to-year basis) [33], the need for further reform of the Ukrainian economy is still as urgent and important as before. Although the principles of national modernization have been consistently developed given the peculiarities of postindustrial reform of national economies, global patterns, and innovative prospects [34], after the global financial and economic crisis of 20082009, which was accompanied by a deep decline in the Ukrainian economy and demonstrated its extreme vulnerability to external threats, the strategic guidelines needed to be reassessed. Subsequently, the Program of Economic Reforms for 2010-2014 Wealthy Society, Competitive Economy, Efficient State was developed, and, in 2015, 
the Strategy for Sustainable Development Ukrai$n e-2020$ was approved. These program documents, despite being conceptually good, were developed in the absence of continuity in the implementation of reforms, regardless of whether and how exactly the previous strategic developments had been implemented and the reasons for failure to perform certain tasks. This did not allow preventing the repetition of mistakes and effective public and testified to inefficient management of transformations. The most important thing was that the complex process of their implementation from design to realization - was not backed with political will, resources, and clear responsibility. Therefore, the outcomes were half-way, at best.

It should be noted that in addition to the strategic documents of the highest level, the Ukrainian public practice had many sectoral programs with reform initiatives, which were implemented during the years of independence with different level of success. For example, the development of the Internal Revenue Code of Ukraine (2010) allowed the codification of relevant legislation and reformed the internal revenue system. The implementation of the provisions of the Concept of Reforming Local Self-Government and Territorial Organization of Governance (2014) significantly increased the financial capacity of the newly formed united territorial communities and contributed to fiscal decentralization. However, not all tasks of these reforms had been solved; in the course of their implementation and later there appeared some aspects that required further steps to regulate the relevant areas of public relations. The public administration reform has long been considered one of the sectoral reforms with a strong strategic potential for modernization. In particular, with the support of both national and international stakeholders, the Public Administration Reform Strategy was adopted in 2016. This Strategy also had adequate financial support from international financial organizations and donors. Despite some positive developments, given the vision of experts directly involved in its implementation, the main goals have not been achieved so far [35]. Undoubtedly, it is too early to evaluate some results of the implementation of these documents, because of the inertia of social processes. However, as regards one of the most modern developments, adopted in March 2021 with the broad involvement of experts, specialists and researchers - the National Economic Strategy for the period up to 2030 - despite some appropriate approaches, a preliminary analysis of its structure indicates the need for further regulation in terms of clear accountability of certain government institutions responsible for the implementation of strategic goals and objectives, since the mechanisms for coordinating the implementation, monitoring, and control of implementation are to some extent recommendatory and non-binding.

The abovementioned facts and sometimes greater external interest in the priority and content of urgent reforms have created the preconditions for institutional uncertainty that may manifest itself in the imitation and distortion of reform processes, replacement of strategic aspects by bureaucratic procedures and so on. To a large extent, these problems are caused by inadequate human resources for reform, as the lack of competence of stakeholders affects the ultimate effectiveness of changes proposed to society by the developers of the transformation agenda. In particular, the Report of the Accounting Chamber of Ukraine on the findings of the audit of the effectiveness of the use of budget funds for measures to implement comprehensive public administration reform contains the conclusions corresponding to the above statements [36].

One of the biggest challenges for continuing reforms, along with numerous external and internal threats, is to compare the number of domestic reforms that may be considered successfully implemented and that of those that have not been brought to a logical end or the results of which the society does not perceive as successful given a number of subjective and objective factors. Unfortunately, the latter is predominant. However, a kind of paradox that may be institutionalized in 
the methodological framework is the fact that the more negative the experience of reforms, the greater the need for reform. This, according to the authors, may be considered a case of increasing utility of reform due to imperfect reforms. Thus, the task of government is to ensure a proper proposal of sound, transparent, and accountable reforms that shall be accepted by society to meet the demand for structural and institutional transformations to ensure inclusive economic growth.

Essentially, despite the general separation from orthodox perception, this interpretation of the value of the reform process, even if not universally recognized, corresponds to the post-institutional aspects of economic theory, in particular the provisions characterizing the complex relationships of institutional units, their subjectivity, and functions that contain definitions of kludges (institutional rules that do not solve the problem, but improve the situation and may ensure the simultaneous operation of old and new institutions) [37], assemblage (combination of hybrid essence, modularity, fragmentation, and exogenous flexibility as inherent properties of economic institutions) [38], and bricolage (adaptive process of forming institutions of various components based on the "bottom-up" principle, by non-professional agents in conditions of permanent resource constraints) [39, 40].

At the same time, these categorical and substantive essences explain the possibility of adaptation of institutions borrowed from another institutional environment to the specific external environment and polymorphism of institutional contexts in different countries. Accordingly, based on the statement proposed by V. Polterovich that the results of transplantation of institutions are determined by the three groups of factors (the sociocultural characteristics; the initial institutional and macroeconomic conditions; the choice of transplantation technology) [41], for the purposes of our study, it should be noted that only the third group of factors is such that it may be suitable for adjusting and finding the most rational form within a targeted policy. Naturally, our own conceptual visions of technological (operational) principles of reform implementation are rather subjective in terms of domestic realities, but at the same time, in our opinion, they give the necessary impetus to find the most effective and viable forms of organization of national reform institutions.

Based on the global problems outlined above, the remoteness of international donors from the reform agenda, the uncertainty of external choice of priorities, and the lack of progress in the vast majority of reforms implemented in a similar way in the national context, given the need for flexibility in complex endogenous and exogenous conditions, it has been proposed to involve reform stakeholders in the development and use of consensus principles for the formation of reform institutions for further use in public practice. It is likely that such an approach is not methodologically perfect at this stage, requires further professional and expert discussion, but in terms of content it is the basic provisions of new technocratic concept of forming reform institutions. To some extent, its emergence may be considered the development of post-institutional economic thought, in particular in the context of the statement of G. Kolodko that reform is a tool, not a goal in itself, and its path is really important [42].

The set of conceptual and generalized proposals corresponding to the above is based on the objective need to systematize and to structure the strategic and tactical aspects of reforming, planning, implementing, and coordinating in the field of public policy reforms. In our opinion, this requires preparation and institutionalization in the national legislative field that regulates the reform process (for example, by preparing a concept, action plan, and draft legal act at the central level of executive and / or legislative power), as well as provision of a clear hierarchy of delegation and responsibility for planning, implementing, and evaluating reform outcomes through establishing a government body with a special status (for example, an agency for the implementation of reforms, with fixed statutory functions, accountability, and the 
status of the administrator of budget funds). This approach, despite being trivial, makes it possible from the very beginning to avoid the accumulated inconsistencies and failures of institutional capacity, which have been deeply rooted in domestic practice over the past 30 years, in particular:

- Reducing contradictions embedded into the general framework of reforms, when the executive body (or its structural subdivision, such as established directorates in central executive bodies) responsible for policy in a particular area, is entrusted with the main tasks of reforming its own activities;

- Creating the preconditions to ensure real transparency and accountability of the reform process, as the successful implementation of reforms is enshrined as a statutory function, with government and public control over reforms becoming objective; in particular, allocating financial mechanisms and resources for reform;

- Eliminating miscoordination or duplication of responsibility and authority of various state bodies, advisory and temporary entities (councils, committees and taskforces for reforms) that are directly or indirectly involved in reforms in relevant areas, without regulatory, institutional and/or resource potential, which substitute these principles for media activity and/or populist/opportunistic behavior.

In addition to the revision and legislative consolidation of the role and functions of the relevant authority, the main novelty of this legal act should be a thorough, inclusive, and unambiguous procedure for planning, organizing, and implementing reforms in all fields of policy formulation and implementation, which should take into consideration the following principles:

- application of an ex ante procedural approach for consensus between the government and the stakeholders of reforms; drafting of the reform concept and its detailed procedural description (reform passport), which should be approved in the prescribed manner at the level of the $\mathrm{Ca}$ binet of Ministers and serve as a framework for legislative support of the reform. This document should include a description of operational processes in the public policy field to be reformed on the basis of applicable legislation; a description of updated process map for each of the adjusted functions (for each administrative process or service in terms of reforming relevant facilities); scope and financial reform plan in accordance with its main stages; officials responsible for the implementation of each of the updated processes during the planned reforms (up to the level of category B civil service positions in compliance with the hierarchy of accountability); as well as initial, intermediate/current and final criteria and performance indicators;

- the application of a separately developed methodology for assessing the socio-economic characteristics of the reform, which should be based on the adaptation of elements of analysis of international organizations (Poverty and Social Impact Analysis, OECD reform priority assessment), as well as thorough qualitative analysis of the planned and the reported (achieved) indicators. In this context, it is advisable to develop and to apply a dual system of the specific (sectoral and approved for specific reform passport) and the general socio-economic indicators (which do not depend on the specific area of reform) at different stages of reform implementation in order to achieve its goals/objectives, and implementation of planned measures (the share of the relevant field of policy formation and implementation in the country's GDP; the growth rate of wage in the relevant field as compared with the national average; the indicators and indices, which determine the country's place in international rankings; the growth rate of investment in the relevant field, and so on are proposed as starting point for the further research);

- the support of reforms, from the stage of preparing its passport to reporting on implementation; systematic sociological (sociological and statistical) surveys and research to ensure proper substantiation of management decisions and to identify aspects of reform, which are impor- 
tant for different groups of agents and stakeholders; feedback at all stages of reform; assessment of the level of public perception of reforms, etc.;

- the setting of limitations and deadlines for reform: for the time horizon from the reform planning to its full institutional functionality shall be at most 3 years; for simultaneous reforms, the scope of fields and objects of reform, which should not exceed the established thresholds in the structure of GDP, while for the reform projects with limited planned redistributive effects, an essential option should be to provide for the possibility of their implementation directly by the authority responsible for the formation and implementation of policy in a certain field (the implementing agency), based on its own concept, as well as on the concept, passport of reforms, and financial plan, as approved in the prescribed manner, with involvement of other agents and reform stakeholders in the supervision, ongoing and final control of the implementing agency;

- the strengthening of coordination between the processes of planning, implementation, and evaluation of reforms and public financial management, in particular in terms of establishing fiscal rules and fiscal and distributive risks of initiating reforms (determining the macroeconomic and financial preconditions for sustainability in the medium and long term); integration of reform processes into the medium-term budget planning; development of relevant budget programs on the basis of reform passports, as precondition for reform and approval of respective financial reform plans; use of special operational and general socio-economic indicators as performance indicators; appropriate expenditure reviews; special procedure for internal and external public financial control and audit of the effectiveness of reforms; independent external audit of reforms;

- the legislative recognition (in the Budget Code of Ukraine) of relevant financial mechanisms for qualifying budget allocations for relevant budget reform programs as protected items of expenditure; avoidance of uncertainty about their sources (impossibility to use optional sources of future revenues, such as privatization proceeds); special nature of expenditure programs in a completely transparent and accountable public order with the possibility of financing part of the assignment in the format of double subordination of different budget managers (the implementing agency and the body responsible for policy in the relevant field of reform);

- the legislative recognition of the special nature of the work process and remuneration conditions for employees of the implementing agency, as well as incentive payments tied to the gradual phased implementation of the reform passport. The total remuneration amount shall be recorded in the reform passport and calculated based on changes in general social economic and special operational indicators;

- the involvement of professional and expert community representatives of national and international reform agents and stakeholders in the process of advisory support of reforms at all stages (the formation of a supervisory board for each reform passport), mainly, on the basis of competitive selection based on clear agreed parameters and criteria for essential representation (for government bodies and state-owned institutions, in accordance with the amount of funding through the state budget; for representatives of private companies, through specialized associations and/or authorized representatives (analytical, expert, and research institutions); for representatives of trade unions and the general public, on the basis of the number of registered members or those who represent more than $50 \%$ of interested stakeholders);

- the specificity of the selection and involvement of the main expert/analytical institution in implementing reforms among specialized research/ university organizations on the basis of an open competition by the reform supervisory board with further provision of basic funding for relevant research projects during the reform imp- 
lementation and evaluation of research activity, given the outcomes of reform upon its completion;

- the specificity of the drafting and consideration of regulations, in accordance with the approved passport;

- the ensuring of an increased level of transparency and accountability of the reform process for society, in particular by conducting public discussions at all stages under a special procedure, namely, by responding to public proposals and keeping their register available for public, regular keeping of a detailed record of all modifications/amendments to the reform passport; drafts of legal acts and regulations prepared on its basis;

- the regulation of expert assistance and financial aid for reforms from international partners and donors by providing exclusive powers to the implementing agency for using such resources, with relevant reform supervisory boards involved; the modernization of financial instruments of the agency.

Conclusions. Thus, regardless of the specificity of formalized content, given the above fundamental properties of the innovative regulation of reform processes, we have proposed to structure the entire cycle of reforming any field of public policy, taking into account the functional parameters the stages of reform process, which given the considerations of further clearer determination, it is expedient to consider the following institutions of reforms as special organizational and structural units:

The Institution for Reform Initiation: a set of regulations, rules, and organizational structures for initiating specific reforms, strategic conciliation and consensual coordination of the initial and planned reform characteristics by agents and stakeholders, determination of bodies responsible for implementation and resource support of reforms;

The Institution for Reform Implementation: a set of regulations, rules, and organizational structures for the implementation of specific reforms, the coordination of the involvement of agents and stakeholders in the tactical and operational aspects of reform;

The Institution for Reform Verification: a set of regulations, rules, and organizational structures to ensure transparency and accountability of the reform process by supervising and monitoring the implementation of specific reforms, achieving their goals and objectives, and the established general socio-economic and specific operational indicators.

Given the above, the main task of the government is to establish a regime for regulation and coordination of reform institutions, which ensures the highest level of transparency, accountability, and inclusion in the modernization of socioeconomic relations to achieve public interests and distribution of public goods in relevant fields the formation and implementation of government policies. Given the theoretical, retrospective, and rational principles of the possible functioning of such an institutional framework, the implementation of these approaches and the formation of the content of reform institutions shall be accompanied by the following attributive variables, as defined in more detail above:

- the formation of the legal framework of reforms, clear definition of delegation process and responsibility, including the political one, for the results of reforms; formalization of reform processes and procedures; envision of instruments to avoid institutional pitfalls in the reform process;

- the qualitative improvement of the process of initiation and supervision of reforms, consensual approval of the system of general socioeconomic and special sectoral indicators for planning and evaluating the results of reforms, identifying opportunities to start and to implement reforms, their priorities, including with the use of OECD methodologies and adaptation of World Bank tools (PSIA);

- the strengthening of the role of dialogue and the involvement of professional and expert communities on the basis of clear qualification cri- 
teria of representativeness; foresight and regulation of the needs for research and expert support;

- the emphasis on economic nature, measurability, and effectiveness of reforms; the strengthening of coordination of reform institutions with macrofinancial forecasting, medium-term budget planning framework; the generalization of fiscal regulations for public finance sustainability; counteraction to fiscal risks and normalization of redistributive effects of reforms;

- the integration of national institutions of reforms into the general institutional context of counteraction to populism [43]; strengthening of expert and analytical support, inclusiveness, deepening of rational character of development of decisions in the field of government policies;

- the regulation of coordination with international partners and donors by establishing a transparent and accountable hierarchy of involvement and use of expert and financial resources for reforms; the development of financial instruments for institutionalization of such cooperation; the enhancement of involving international and institutional stakeholders in reform supervisory boards.

\section{REFERENCES}

1. Bearce, D., Tirone, D. (2010). Foreign Aid Effectiveness and the Strategic Goals of Donor Governments. The Journal of Politics, 72(3), 837-851. https://doi.org/1017/S0022381610000204

2. Burnside, C., Dollar, D. (2000). Aid, Policies, and Growth. American Economic Review, 90(4), 847-868. https://doi. org/10.1257/aer.90.4.847

3. Dreher, A., Nunnenkamp, P., Thiele, R. (2008). Does US Aid Buy UN General Assembly Votes? A Disaggregated Analysis. Public Choice, 136, 139-164. https://doi.org/10.2139/ssrn.910900

4. Swiss, L., Longhofer, W. (2016). Membership Has Its Privileges: Shared International Organizational Affiliation and Foreign Aid Flows, 1978-2010. Social Forces, 94(4), 1769-1793. https://doi.org/10.1093/sf/sov117

5. Polterovich, V. (1999). Institutional Traps and Economic Reforms. Economics and Mathematical Methods, 35(2), 1-37. URL: https://mpra.ub.uni-muenchen.de/27257/1/MPRA_paper_27257.pdf (Last accessed: 30.07.2020) [in Russian].

6. Hill, H. (2013).The Political Economy of Policy Reform: Insights from Southeast Asia. Asian Development Review, 30(1), 108-130. URL: https://www.mitpressjournals.org/doi/pdf/10.1162/ADEV_a_00005 (Last accessed: 30.07.2020).

7. Williamson, J. (1990). Latin American Adjustment: How Much Has Happene $\bar{d}$ ? Washington: Institute for International Economics. 445 p. URL: https://www.piie.com/commentary/speeches-papers/what-washington-means-policy-reform (Last accessed: 30.07.2020).

8. Rodrik, D. (1996). Understanding Economic Policy Reform. Journal of Economic Literature, 34(1), 9-41.

9. Stiglitz, J. (1998). More Instruments and Broader Goals: Moving Toward the Post-Washington Consensus. The United Nations University World Institute for Development Economics Research Annual Lecture (7th January 1998, Helsinki, Finland). URL: https://archive.globalpolicy.org/component/content/article/209-bwi-wto/43245.html (Last accessed: 30.07.2020).

10. Williamson, J. (2003). From Reforms Agenda to Damaged Brand Name. Finance and development, 40(3), 10-13. URL: https://www.imf.org/external/pubs/ft/fandd/2003/09/pdf/williams.pdf (Last accessed: 30.07.2020).

11. Serra, N., Stiglitz, J. (2008). The Washington Consensus Reconsidered: Towards a New Global Governance. Oxford: Oxford University Press. 382 p. https://doi.org/10.1093/acprof:oso/9780199534081.001.0001

12. Bird, R. (2003). Managing the Reform Process. Toronto: University of Toronto. URL: https://www.researchgate.net/publication/24137631_Managing the Reform_Process (Last accessed: 30.07.2020).

13. Lau, L., Qian, Y., Roland, G. (2000). Reform Without Losers: An Interpretation of China's Dual-Track Approach to Transition. Journal of Political Economy, 108(1), 120-143. https://doi.org/10.1086/262113

14. Fernandez, R., Rodrik, D. (1991). Resistance to Reform: Status Quo Bias in the Presence of Individual-Specific Uncertainty. American Economic Review, 81(5), 1146-1155.

15. Alesina, A., Roubini, N. (1992). Political Cycles in OECD Economies. Review of Economic Studies, 59(4), 663-688.

16. Krueger, A., Rajapatirana, S. (1999). The World Bank Policies Towards Trade and Trade Policy Reform. The World Econo$m y, 22(6), 717-740$. https://doi.org/10.1111/1467-9701.00229

17. Haggard, S., Webb, S. (1994). Voting for Reform: Democracy, Political Liberalization, and Economic Adjustment. New York: Oxford University Press. 519 p. URL: https://documents1.worldbank.org/curated/en/116811468760536681/pdf/multi0page.pdf (Last accessed: 30.07.2020). 
18. Olofsgard, A. (2003). The Political Economy of Reform: Institutional Change as a Tool for Political Credibility. Washington: World Bank. URL: https://openknowledge.worldbank.org/handle/10986/9232 (Last accessed: 30.07.2020).

19. Making Reform Happen: Lessons from OECD Countries. OECD. (2010). URL: https://www.oecd-ilibrary.org/deliver? redirecturl=http\%3A\%2F\%2Fwww.keepeek.com\%2FDigital-Asset-Management\%2Foecd\%2Feconomics\%2Fmakingreform-happen_9789264086296-en\&isPreview=true\&itemId=\%2Fcontent\%2Fpublication\%2F9789264086296-en (Last accessed: 30.07.2020). https://doi.org/10.1787/9789264086296-en.

20. Gasanov, S. (2012). Structural Transformations of Economy and Public Finances: Problems of Methodology, Theory, Economic Policy. Kyiv: State Educational and Scientific Establishment "Academy for Financial Management". 352 p. [in Ukrainian].

21. Economic Growth in the 1990s: Learning from a Decade of Reform. World Bank (2005). URL: https://openknowledge. worldbank.org/handle/10986/7370 (Last accessed: 30.07.2020).

22. The Political Economy of Policy Reform: Issues and Implications for Policy Dialogue and Development Operations. World Bank (2008). Washington: World Bank. URL: https://openknowledge.worldbank.org/handle/10986/7782 (Last accessed: 30.07.2020).

23. Analyzing the Effects of Policy Reforms on the Poor: An Evaluation of the Effectiveness of World Bank Support to Poverty and Social Impact Analyses. Independent Evaluation Group, World Bank (2010). URL: https://openknowledge. worldbank.org/handle/10986/2484 (Last accessed: 30.07.2020).

24. Johann, M., Orlando, M. (2016). Poverty and Social Impact Analysis (PSIA): Multi-Donor Trust Fund - Final Report 2016. Washington: World Bank Group. URL: http://documents.worldbank.org/curated/en/701191479977368846/Povertyand-social-impact-analysis-PSIA-multi-donor-trust-fund-final-report-2016 (Last accessed: 30.07.2020).

25. Poverty and Social Impact Analysis Online Community. URL: https://collaboration.worldbank.org/content/sites/collaboration-for-development/en/groups/poverty-and-social-impact-analysis-online-community.html (Last accessed: 30.07.2020).

26. Easterly, W. (2001). The Lost Decades: Developing Countries' Stagnation in Spite of Policy Reform 1980-1998. Journal of Economic Growth, 6(2), 135-157. https://doi.org/10.1023/A:1011378507540

27. Easterly, W. (2019). In Search of Reforms for Growth: New Stylized Facts on Policy and Growth Outcomes. NBER Working Papers 26318. URL: https://www.nber.org/papers/w26318.pdf(Last accessed: 30.07.2020). https://doi.org/10.3386/ w26318

28. Andrews, M. (2018). Creating luck in development. The new challenge. URL: https://matthewandrews.typepad.com/ files/exec-ed-march-2018.pdf (Last accessed: 30.07.2020).

29. Andrews, M. (2018). Governance reform in international development. URL: https://matthewandrews.typepad.com/ mattandrews/ (Last accessed: 30.07.2020).

30. Economic Policy Reforms 2016. Going for Growth Interim Report. OECD (2016). URL: http://www.oecd.org/economy/growth/Going-for-Growth-2016-Overview-of-structural-reforms-in-the-policy-areas-identified-as-priorities-forgrowth.pdf (Last accessed: 30.07.2020). https://doi.org/10.1787/growth-2016-en

31. Economic Policy Reforms 2019: Going for Growth. OECD. (2019). URL: https://www.oecd-ilibrary.org/sites/aec5b059en/index.html?itemId=/content/publication/aec5b059-en (Last accessed: 30.07.2020). https://doi.org/10.1787/aec5b059-en

32. The Political Costs of Reforms: Fear or Reality? International Monetary Fund. (2019). URL: https://www.imf.org/ / media/Files/Publications/SDN/2019/SDNEA19008.ashx (Last accessed: 30.07.2020).

33. Heyets, V. (2004). Lessons and Prospects of Market Reforms and Long-Term Economic Growth in Ukraine. Economic theory, 2, 3-24. URL: http://etet.org.ua/?page_id $=189 \&$ year $=2004 \&$ issueno $=2 \&$ begin_page $=3 \&$ mode $=$ get_ art\&flang $=\mathrm{uk}$ (Last accessed: 30.07.2020) [in Ukrainian].

34. Heyets, V., Semynozhenko, V. (2006). Innovation Prospects of Ukraine. Kharkiv: Constanta. 272 p. [in Ukrainian].

35. Soroka, S. (2021). Institutions vs Revolutions. Public Service. URL: https://zn.ua/ukr/internal/institutsiji-vs-revoljutsiji-derzhsluzhba.html (Last accessed: 12.02.2021) [in Ukrainian].

36. Report on Results of Efficiency Audit Concerning Public Expenditures of State Budget for Implementation of Public Administration Complex Reform. Accounting Chamber of Ukraine (2018). URL: https://rp.gov.ua/upload-files/Activity/Collegium/2018/27-1_2018/Zvit_27-1_2018.pdf (Last accessed: 30.07.2020) [in Ukrainian].

37. Kawai, K., Ruitian, L., Li, H. (2018). Political Kludges. American Economic Journal: Microeconomics, 10(4), 131-158. URL: https://www.aeaweb.org/articles?id=10.1257/mic.20150242 (Last accessed: 30.07.2020). https://doi.org/10.1257/mic.20150242

38. DeLanda, M. (2006). A New Philosophy Of Society: Assemblage Theory And Social Complexity. London: Continuum. 150 p.

39. Cleaver, F., de Koning, J. (2015). Furthering Critical Institutionalism. International Journal of the Commons, 9(1), 1-18. URL: https://www.thecommonsjournal.org/articles/10.18352/ijc.605/ (Last accessed: 30.07.2020). https://doi.org/ 10.18352/ijc.605 
40. Frolov, D. (2020). Post-Institutionalism: Beyond the Institutional Mainstream. Voprosy Ekonomiki, 5, 107-140. https:// doi.org/10.32609/0042-8736-2020-5-107-140 [In Russian].

41. Polterovich, V. (2001). Transplantation of Economic Institutes. Economics of Contemporary Russia, 3, 24-50. [in Russian].

42. Kolodko, G. (2014). Reforms are Tools, But Not End In Itself. Business, 39(1130), 8-9. URL: http://tiger.edu.pl/ aktualnosci/2014/wywiad-257.pdf (Last accessed: 12.03.2021) [in Russian].

43. Sokolovska, A. M., Kotlyarevskyy, Ya. V. (2020). Scientific Discourse of Populism: Aspects of Economy and Tax Policy. Sci. innov, 16(5), 36-51. https://doi.org/10.15407/scine16.05.036

Received 18.08.2020

Revised 07.04.2021

Accepted 09.04.2021

Я.В. Котляревський ${ }^{1}$ (https://orcid.org/0000-0003-3542-6952),

А.М. Соколовська ${ }^{2}$ (https://orcid.org/0000-0002-1022-8215)

${ }^{1}$ Міністерство фінансів України,

вул. Михайла Грушевського, 12/2, Київ, 02000, Україна,

+380 44201 5630, infomf@minfin.gov.ua

2 Державна навчально-наукова установа «Академія фінансового управління»,

б-р Дружби Народів, 38, Київ, 01103, Україна,

+380 44277 5115, afu@afu.kiev.ua

\section{ТЕОРЕТИЧНІ ТА ПРИКЛАДНІ АСПЕКТИ РОЗВИТКУ ІНСТИТУТІВ РЕФОРМ У ГЛОБАЛЬНОМУ Й НАЦІОНАЛЬНОМУ ВИМІРАХ}

Вступ. Неоднозначність у оцінках результатів реформ державних політик та відсутність методологічного консенсусу щодо найбільш придатних підходів до ініціації й впровадження економічних реформ, а також подальше ускладнення інституціональних умов у глобальному та національному вимірах, потребують більш грунтовного висвітлення підходів до пізнання змісту, структури, технології впровадження й оцінювання наслідків реформ.

Проблематика. Загострення протиріч та накопичення кризових явищ у функціонуванні світової економіки, потреби фіскальної консолідації та одночасного стимулювання економічного зростання національних економік в середньостроковій перспективі потребують виокремлення наукових підходів та напрацювання відповідних прикладних аспектів найбільш транспарентного, підзвітного та раціонального проєктування національних інститутів реформ.

Мета. Узагальнити, структурувати та систематизувати відомості щодо теоретичних та прикладних засад впровадження реформ державних політик у контексті удосконалення підходів до проєктування та оцінювання їхніх наслідків та визначити шляхи підвищення результативності економічних реформ в Україні.

Матеріали й методи. Використано методи ретроспективного та порівняльного аналізу для визначення еволюції методологічного інструментарію теорії реформ; фактологічного аналізу - для обгрунтування плюралізму підходів наукових шкіл та міжнародних організацій до детермінації реформ, їх змісту та наслідків.

Результати. Систематизовано підходи дослідників до аналізу реформ з акцентуванням важливості усвідомлення викликів, пов'язаних із соціальними та перерозподільчими ефектами реформ, викладено підходи щодо структуризації стратегічних і тактичних аспектів реформування на основі виокремлення національних інститутів реформ.

Висновки. Узагальнено теоретичні та прикладні аспекти дослідження й регулювання процесів реформ державних політик у глобальному й національному контекстах, запропоновано підходи до розвитку національних інститутів реформ.

Ключові слова: реформи, теорія реформ, економіка, інститути, інклюзивність, державна політика. 